\title{
Dysphagia caused by an inverted papilloma
}

\author{
Luís Cardoso, João Fonseca Neves, João Carlos Ribeiro
}

Centro Hospitalar e Universitario de Coimbra EPE, Coimbra, Portugal

\section{Correspondence to}

Dr Luís Cardoso,

luis.cardoso@gmail.com

Accepted 28 November 2017

\section{DESCRIPTION}

A previously healthy 57-year-old man presented with progressive dysphagia and sore throat with 1-month duration. Nasal obstruction was present but neglected. Examination revealed an enormous mass in the posterior wall of the oropharynx (figure 1) pending from the nasopharynx (figure 2), blocking the left nasal cavity and reaching the epiglottis. Differential diagnosis includes benign lesions such antrochoanal polyp, inflammatory polyp, angiofibroma or encephalocele and malignant neoplasms like epidermoid carcinoma or adenocarcinoma. ${ }^{1}$ At the beginning, for its clinical appearance, it was considered as an antrochoanal polyp. An office biopsy was performed, and the histopathological report confirmed a benign inverted papilloma with an exceptional presentation. A $14 \mathrm{~cm}$ inverted papilloma, arising from the left lateral nasal wall, was endoscopically resected, and no recurrence occurred after 1 year of follow-up. Unlike other benign lesions, close follow-up is mandatory in inverted papillomas because recurrence occur in $12 \%-15 \%$ and malignant transformation in $7 \%-9 \% .^{23}$

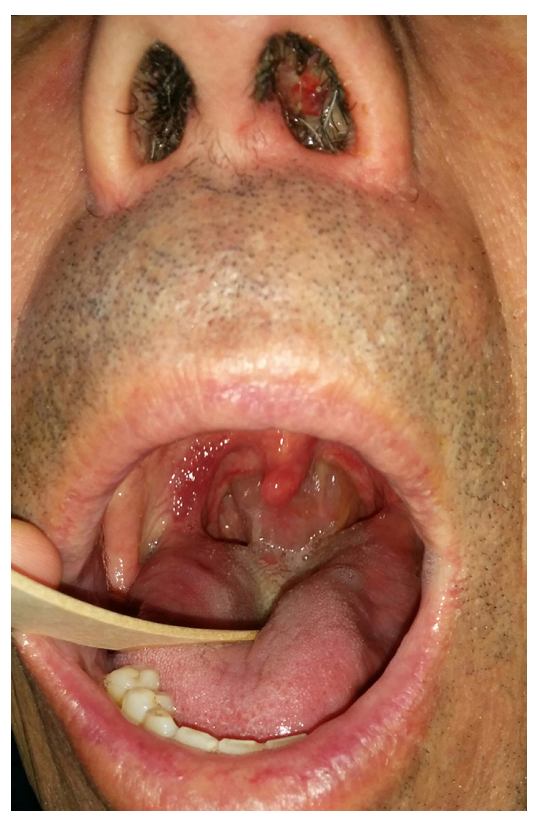

Figure 1 Papilloma in the posterior wall of the oropharynx.

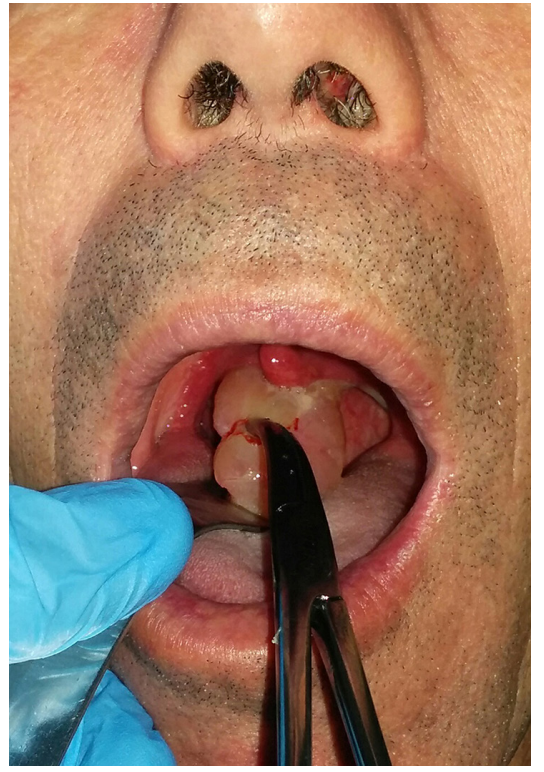

Figure 2 Papilloma being pulled out from the back of the nose to the mouth with forceps.

\section{Learning points}

- Large inverted papilloma can be a cause of dysphagia.

- Inverted papillomas are macroscopically indistinguishable from other nasal lesions.

- This case exemplifies the importance of seeing beyond the obvious and keeping in mind a vast differential diagnosis.

Contributors All authors contributed to the manuscript as follows: LC drafted the article. JFN revision of the article. JCR final approval of the version to be published. All authors read and approved the final manuscript.

Competing interests None declared.

Patient consent Obtained.

Provenance and peer review Not commissioned; externally peer reviewed.

(c) BMJ Publishing Group Ltd (unless otherwise stated in the text of the article) 2017. All rights reserved. No commercial use is permitted unless otherwise expressly granted.

\section{REFERENCES}

1 London NR, Reh DD. Differential diagnosis of chronic rhinosinusitis with nasal polyps. Adv Otorhinolaryngol 2016;79:1-12.

2 Attlmayr B, Derbyshire SG, Kasbekar AV, et al. Management of inverted papilloma: review. J Laryngol Otol 2017;131:284-9.

3 Busquets JM, Hwang PH. Endoscopic resection of sinonasal inverted papilloma: a meta-analysis. Otolaryngol Head Neck Surg 2006;134:476-82. 
Copyright 2017 BMJ Publishing Group. All rights reserved. For permission to reuse any of this content visit http://group.bmj.com/group/rights-licensing/permissions.

BMJ Case Report Fellows may re-use this article for personal use and teaching without any further permission.

Become a Fellow of BMJ Case Reports today and you can:

- Submit as many cases as you like

- Enjoy fast sympathetic peer review and rapid publication of accepted articles

Access all the published articles

- Re-use any of the published material for personal use and teaching without further permission

For information on Institutional Fellowships contact consortiasales@bmjgroup.com

Visit casereports.bmj.com for more articles like this and to become a Fellow 